\title{
The Implementation of Sustainable Manufacturing Practice in Textile Industry: An Indonesian Perspective*
}

\author{
Muhardi MUHARDI ${ }^{1}$, Cici CINTYAWATI ${ }^{2}$, Rabiatul ADWIYAH ${ }^{3}$, Norsiah HAMI ${ }^{4}$, Rushanim HASHIM ${ }^{5}$, \\ Salmah OMAR ${ }^{6}$, Shafini Mohd SHAFIE ${ }^{7}$
}

Received: August 01, 2020 Revised: September 30, 2020 Accepted: October 15, 2020

\begin{abstract}
The intention of this paper is to give a better understanding about the implementation of sustainable manufacturing practice in the textile companies in Indonesia as one of the promising sectors in the manufacturing industry. The data was collected by taking a case study approach in one of the leading textile companies in Indonesia. Questionnaire and interview techniques were used to gather in-depth information about the implementation of a sustainable concept in the company. The result reveals that the extent of the implementation of Sustainable Manufacturing Practices (SMP) in the companies are at a level of moderate to high. From the three dimensions measured which are environment, economy, and social dimensions, the evaluation result shows good performance in terms of the implementation of sustainable concepts, like low level of gas emission, high percentage of renewable energy usage, cost reduction rate, high quality of life, etc. From this result, the authors then develop a sustainable manufacturing model in the wider coverage to be implemented not only in the textile industry but is expected to be implemented in manufacturing sectors as well. This model consists of at least seven basic archetypes which are divided into three dominant areas: technological innovation, economical, and social areas which aim to bring better performance in the manufacturing industry of Indonesia.
\end{abstract}

Keywords: Manufacturing Industry, Textile Industry, Sustainable Development Goals, Sustainable Manufacturing Practice

JEL Classification Code: F18, F63, L11, O14, O44

\section{Introduction}

The average consumption pattern of the global community continues to increase, although this pattern is

\footnotetext{
*Acknowledgements:

Financial support for this study was provided by a grant from Universitas Islam Bandung (UNISBA) and Universiti Utara Malaysia (UUM). The authors wish to thank 1st Vice Rector of UNISBA and Vice Chancellor of UUM to initiate this research collaboration between UNISBA dan UUM.

${ }^{1}$ First Author and Corresponding Author. Professor. Faculty of Economics and Business, Universitas Islam Bandung, Indonesia [Postal Address: Purnawarman Street, No. 59, Tamansari, Bandung Wetan, Bandung, West Java, 40117, Indonesia]

Email: hardi.pasca@gmail.com

${ }^{2}$ Lecturer. Faculty of Economics and Business, Universitas Islam Bandung, Indonesia. Email: cici.cintyawati94@gmail.com

${ }^{3}$ Lecturer. Faculty of Economics and Business, Universitas Islam Bandung, Indonesia. Email: rabiatul1989@gmail.com

${ }^{4}$ Lecturer. School of Technology Management and Logistics, Universiti Utara Malaysia, Malaysia.

Email: norsiahami@uum.edu.my
}

varied from region to region due to the influence of local cultural, social, and even economic factors. The increased level of consumption issues then makes the manufacturing industry growth as inevitable (Sangwan \& Mittal, 2015; Amaranti et al., 2017) and finally making it one of the sectors that drives the economy (Nguyen and Nguyen, 2020). Globalization, population, and technological development have also made a very large impact on the manufacturing industry throughout the world, in addition to influencing competition for increasingly stringent markets, as well as

\footnotetext{
${ }^{5}$ Lecturer. School of Technology Management and Logistics, Universiti Utara Malaysia, Malaysia. Email: rushanim@uum.edu.my ${ }^{6}$ Lecturer. School of Technology Management and Logistics, Universiti Utara Malaysia, Malaysia. Email: salmah@uum.edu.my ${ }^{7}$ Lecturer. School of Technology Management and Logistics, Universiti Utara Malaysia, Malaysia. Email: shafini@uum.edu.my

(c) Copyright: The Author(s)

This is an Open Access article distributed under the terms of the Creative Commons Attribution Non-Commercial License (https://creativecommons.org/licenses/by-nc/4.0/) which permits unrestricted non-commercial use, distribution, and reproduction in any medium, provided the original work is properly cited.
} 
greater energy and natural resource needs in order to produce more products (Hami et al., 2015; Amaranti et al., 2017). Instead of increasing the needs for natural resources, the rapid growth of the manufacturing industry has also created many economic, environmental, and social problems like creating more environmental issues (Sangwan, 2011; Choi et al., 2019), like pollution, global warming, waste production, climate change, resource scarcity, etc. To reduce these issues, it is important to apply sustainable practices as a habit in the daily activities (Khan et al., 2020) of the manufacturing sector.

With an increase in these issues, sustainable manufacturing has gathered more attention and has become one of the important agendas for countries in the world for the last few decades, including in Indonesia. In Indonesia, sustainable manufacturing implementation is in line with the implementation of the 2030 agenda regarding the implementation of the Sustainable Development Goals (SDGs) to create a paradigm shift towards development based on human rights and equality in keeping with the goal of attaining "No One Left Behind" (Jones et al., 2016) since this sustainability manufacturing agenda can encourage business players to grow together in the highly intense global business competition. The basis of this sustainable manufacturing is the concept of recycling, where a product or process is no longer only seen from the manufacturing process but also from the entire recycling process, starting from the procurement of raw materials, finished products, to the use, stage of use, and end of life of the product (Hanafi, 2016).

Given the importance of sustainable manufacturing implementation, many researchers give more consideration to study about this concept and its implementation in developed countries, but there is a lack of study about the implementation of this issue in developing countries like Indonesia as its implementation is still limited. Meanwhile, sustainable manufacturing can be the key to reach the Indonesian SDGs goal by 2030.

In this study, the researchers are more focused on the textile industry as one of the manufacturing business types that has a great potential to create environmental issues in Indonesia, especially in Bandung which is well known for its textile products. Therefore, the aim of this research is to measure the sustainability of several textile manufacturers in Bandung, West Java Province, Indonesia, from the perspective of environmental preservation, society, and economy. The focus of this research is to identify various challenges and problems faced in implementing the sustainable manufacturing practices, and the efforts taken by several textile manufacturers in the Bandung City to overcome these problems.

Researches about the implementation of sustainable manufacturing practices in the textile industry in Indonesia is still limited since most of researchers were more focused on other sectors, like on the SMEs sector (Fatimah et al., 2013) or they have just described the general view of sustainable manufacturing concept in the Indonesian manufacturing sector (Hanafi, 2016). In addition, most of the studies conducted in Indonesia were also more focused in specific contexts like green supply chain practices (Ariyanti, 2018; Djunaidi et al., 2018; Roespinoedji et al., 2019; Thaib, 2020). Meanwhile, in this study, researchers have tried to give a wider analysis about the implementation of sustainable practices, not only in a green (environment) context, but also in an economic and social context by dividing the parameters into those three parts (Nurlanova, et al., 2020).

\section{Literature Review}

\subsection{Sustainable Manufacturing Practice (SMP)}

There are many studies conducted to give better understanding about the SMP concept, but still there are no common definitions among scholars related to the definition of sustainable manufacturing since this concept has kept on developing and modifying from year to year (Moldavska \& Welo, 2017). According to the United States Environmental Agency in 2107, sustainable manufacturing is focused on how to create manufactured products in a better way, in terms of reducing negative impacts on the environment because of production processes. This concept not only focused on how to create final products in a wiser way, but it is also concerned about how to help the employees to get a safer workplace as well as provide more benefits to the community around the plant (EPA, 2010). This definition was supported by Roberts and Ball in 2014. The difference is only in adding consumers' safety as an additional concern that needs to be added in the application of this concept, and not just be concerned with employees and the community. In the end, sustainable concept is not the only concern about the environment, but also socio-economic aspects (Nurlanova et al., 2020).

To Summarize, sustainable manufacturing practices can be defined as the techniques, policies and procedures that can be applied by companies to produce their manufactured products by reducing negative impacts on the environment, and give more attention to the safety of employees, communities, and consumers.

\subsection{Sustainable Manufacturing Parameters}

According to Bhanot et al. (2015), sustainable manufacturing parameters were divided into three parts. First is the economic dimension which consists of four parameters: Production Cost, Cutting Quality, Production 
Rate, and Process Management. Second is environmental dimensions, divided into five parameters: Water Intensity, Energy Intensity, Materials, Waste Management, and Environmental Regulations. And the third and the last is the social dimension which consists of four parameters: Worker Health, Worker Safety, Labor Relations, and Training and Education. These dimensions and parameters become a reference in evaluating the practices of sustainable manufacturing processes as the object of this research. Each dimension has different parameters, such as the economic dimension which has several parameters measured to increase the economic benefits. In the social dimension, the parameters used refer more to the aim of providing employees' welfare, in terms of their health, working hours, and other aspects. Meanwhile, in the environmental dimension, the parameters measured aim to reduce the negative impacts resulting from production activities, like material selection, natural resources used, and waste management carried out by the company, etc.

\subsection{Stages in Implementing Sustainable Manufacturing}

As explained by Gam et al. (2009) in their study, scholars have discussed many types of stages in implementing sustainable manufacturing in the company. From several studies, they have summarized about the stages used in implementing sustainable manufacturing concepts. They divided the steps into four main steps, which are: (1) problem definition and research, (2) sample making, (3) solution development and collaboration, and (4) production. In the first step, a company firstly should define problems faced and should analyze the market to get in-depth information about the current situation, both in internal and external matters of the company. A research is needed to get a wider understanding related to the problems or issues. The second step is making a sample in terms of materials testing, designing, cost planning, and testing process. It aims to make sure that the product fulfills the market needs and the company has ability to produce the needed products. In the third step, a company needs to do more collaboration in developing the products, like sharing knowledge, resources, ideas, etc. with other parties (internal or external parties). Then, the last step is production which is related to the production process such as the usage of water, materials, energy, and other resources, until the process of waste management to make sure about the negative impacts of the production process to the environment can be minimized (Gam et al., 2009). Those steps then become a reference in modeling sustainable manufacturing, by concern in creating innovation in three pillars or dimensions, which are technological, innovation, and organizational pillars (Bocken et al., 2014).

\section{Research Methods and Materials}

To reach the aims of this study, a case study method is used to provide a broader picture and information about the sustainable manufacturing issues faced in the company studied. To collect the data needed, the tools used are semi-structured interview to operation manager (around 30 minutes per informant), questionnaire, and review of secondary information sources. Data used in this research are primary data using interviews, questionnaires, and secondary data related to the parameters measured, like the usage of energy, materials, workers' health, waste management, etc.

In designing this study, problem identification becomes the first stage used in this research. In this research, the authors try to highlight the sustainable manufacturing issues in the companies. To support the analysis of this research, the authors review some literature from some sources like journals, books, articles, etc. The basic concept of this research is the sustainable manufacturing concept. After creating some critical review, the next stage is data collection by using two types of data which are primary and secondary data. From the interview process, the data obtained will be coded to get important points and the data gathered from the questionnaire will be summarized in one table to get sustainable manufacturing evaluation result. Form this evaluation results, a sustainable manufacturing model will be built and then be analyzed and concluded so that the authors can give some recommendation for stakeholders involved as a consideration in making decisions.

In this study, the authors will gather data about the three main pillars of sustainability in the manufacturing industry which includes social, economic, and environmental aspects. In choosing the object of this study, the researchers will focus on a single big textile company in Bandung which is Daliatex Kusuma Co. in order to make an in-depth research. This company is one of the leading textile manufacturers in Indonesia. This company is located in Bandung City, West Java, Indonesia. This company was chosen since it applied a sustainable manufacturing concept in producing their innovative knit fabric products. By using this company as the research object, it is expected that it can bring more insights about the sustainable manufacturing practices in Indonesia, especially in the textile industry.

\section{Results and Discussion}

\subsection{Sustainable Manufacturing Practice (SMP) Evaluation}

The evaluation of SMP in Daliatex Company was divided into 3 parts, which are environmental, economic, and social 
factors as described in Table 1. Those areas are divided into five factors and each factor has different parameters which were adopted from the previous researches conducted by many scholars. In terms of environmental impacts, there are seven parameters which are related to the rate of gas emission, pollutants, business footprint, renewable energy usage, and groundwater usage. The next factor is energy consumption, like energy usage and efficiency. The third factor is employee health to guarantee the health and safety of the employees through the provision of health facilities and insurance. The fourth factor is much related with manufacturing cost, in line with the purpose of cost reduction practice in the company. And the last factor is much related with the waste management or the application of reduce, reuse, and recycle concept.

From the Table 1 above, the evaluation result of sustainable manufacturing practices in the company are good. In terms of environmental dimensions, almost all parameters showed good performance, like the low usage of energy, low level of gas emission, low number of waste waters, high percentage of renewable resource usage, etc. Then, in terms of economic dimensions, the company also can reduce their production cost but can still maintain a high production rate. Last, in terms of social dimension, the company has provided facilities to give a better quality of life and safety environment for their employees.

Table 1: Example of a Table Caption

\begin{tabular}{|c|c|c|}
\hline Factors & Sub-Factors & Result \\
\hline \multirow{7}{*}{$\begin{array}{l}\text { Environmental } \\
\text { Impacts }\end{array}$} & The usage of eco- friendly transportation & High (> 80\% employees using bicycle) \\
\hline & $\mathrm{CO}_{2}$ per emission per unit & Low $(<5 \%)$, the usage of sustainable technology \\
\hline & Pollutants in ground water & High (above the quality standard limits) \\
\hline & Contaminant of water pollution & Low (around $2 \%$ ), the usage of waste treatment technology \\
\hline & Business Footprints & Has been producing high-quality knit fabrics \\
\hline & $\%$ of renewable energy using & High $(90 \%)$, the usage of solar energy) \\
\hline & Level of ground water (clean water) & High, the company utilize surface water from the river \\
\hline \multirow{4}{*}{$\begin{array}{l}\text { Energy } \\
\text { Consumption }\end{array}$} & Rate of energy saving & High (rule about turning off electricity when it is not needed) \\
\hline & Rate of energy recapture & High \\
\hline & Energy efficiency/unit & $\begin{array}{l}\text { Low (The energy efficiency was decreased compared to the } \\
\text { previous year ( } 0.92 \mathrm{GJ} / \text { ton of production) and did not meet } \\
\text { the KES standard of } 0.6 \mathrm{GJ} / \text { ton of production) }\end{array}$ \\
\hline & Total energy/unit & Moderate $(255,630 \mathrm{kWh} /$ ton or equivalent to $0.92 \mathrm{GJ} /$ ton $)$ \\
\hline \multirow{5}{*}{$\begin{array}{l}\text { Employee's } \\
\text { (Personal) } \\
\text { Health }\end{array}$} & Number of health facility & Moderate (There is a clinic and 6 medical staffs) \\
\hline & Sick/workdays ratio & Low (2 people / 6 working days) \\
\hline & Health Insurance & Moderate (Using the Social Security Agency / BPJS) \\
\hline & Sport Facilities & Moderate (Football and Volley Fields) \\
\hline & Health Index & Moderate \\
\hline \multirow{5}{*}{$\begin{array}{l}\text { Manufacturing } \\
\text { cost }\end{array}$} & Steel consumption/unit & Moderate ( \pm 20 ton per unit) \\
\hline & Aluminum consumption/unit & Moderate $( \pm 34$ ton per unit) \\
\hline & Plastic consumption/unit & High ( \pm 60 ton per unit) \\
\hline & $\begin{array}{l}\text { Cost saving by increasing energy } \\
\text { efficiency }\end{array}$ & Low (USD 304 Millions) \\
\hline & Energy costs/unit & Moderate (USD 65 Billion) \\
\hline \multirow{3}{*}{$\begin{array}{l}\text { Waste } \\
\text { management }\end{array}$} & Recycling waste/unit & Moderate (15 tons of fly ash and 5 tons of basic ash) \\
\hline & Waste Quality & Moderate \\
\hline & Waste Recycling Technology & Moderate \\
\hline
\end{tabular}




\subsection{Stages in Implementing Sustainable Manufacturing}

In step (1) Daliatex company analyzes problems or issues faced to make sure that they can create products that are producible and marketable since one of their priorities is providing high quality knit fabrics to their customers. They used the $\mathrm{R}$ and $\mathrm{D}$ department as a media to conduct research based on the current market situation and customer analysis results. Step (2), sample making, includes "material selection and testing" and "cost and design evaluation." In this step, the company selects their material appropriately to reduce their cost to optimizing their supply chain process. In this stage, they also choose environmentally friendly materials to reduce negative impacts of their products to the environment. They always make sure to do continuous improvement in creating their knit fabrics product, by upgrading their technology and production process. In terms of energy used, they also used solar energy (around $90 \%$ ) to participate in preserving the environment. Step (3) is solution development and collaboration. The company is trying to collaborate with other companies to make use of their resources and to develop a better solution for their problems. The explanation for each company is below: a. Daliatex Kusuma: Producing Woven fabrics, MVS Viscose \& Blended Yarn, and Circular Knit Fabrics.

b. Intermoda Kusuma: Producing Warp Knit Fabrics.

c. Indachi Prima: Producing Nylon Yarn for Textile and Non-textile.

d. Urase Prima: Producing Polyester Woven Fabrics.

Step (4) is production. In their production process, Daliatex Company has a commitment in reducing negative impacts of their company's activity on the environment. There are several programs conducted in the company related with the production activities like waste management program through waste recycling activity, the usage of renewable energy, reducing gas emission, creating more safety environment measures for their workers, and other efforts to reduce the negative impacts on the environment.

\subsection{Sustainable Manufacturing Model}

The last stages in this research is to build a sustainable model to be used in the manufacturing company. Figure 1 describes the Sustainable Manufacturing Model created in this research. More explanation about the sustainable manufacturing model shown in Figure 1 below.

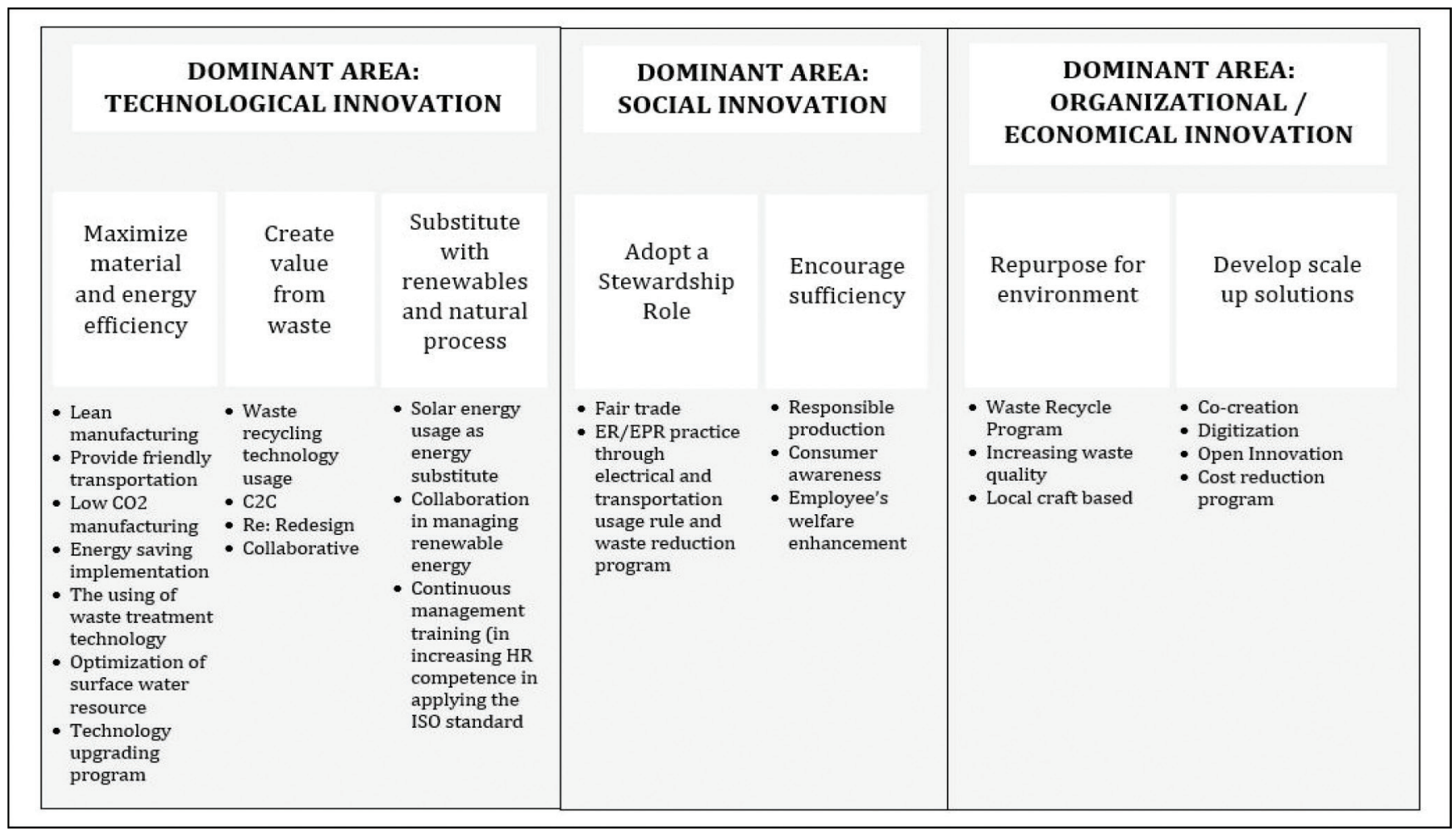

Figure 1: Sustainable Manufacturing Model 


\subsubsection{Technological Innovation}

Maximize material and energy efficiency: used by the company to maximize materials usage during production processes and to make the energy used by the company more efficient. To reach that aims, Daliatex company made several efforts, like using renewable energy (solar energy) around $90 \%$ in its work processes to fulfill energy needs in the production activities, reducing gas emission (through the usage of sustainable technology and eco-friendly public transportation around the company), the usage of ecofriendly materials, etc.

Create Value from Waste: related to how a company is using the concept of restoration, rather than disposability. In this concept, the company is using multiple cycles of disassembly for its products, components, and materials to optimize their function and reuse them. The application of this concept is like the usage of technology to recycle the waste produced by the company and make collaboration with other parties to implement this strategy.

Substitute with renewables and natural processes: using renewable and eco-friendly materials and solar energy, reducing water and gas pollution, recycling the waste resulting from the production activity (using waste recycling technology), etc.

\subsubsection{Social Innovation}

Adopt a stewardship role: to make sure that the company can deliver safety and high-quality products to their consumers and to create sustainable products who have fewer negative impacts not only to the environment, but also to their customers and community. The implementation of this strategy was shown in the company by applying Extended Responsibility or Environmental Producers' Responsibility through the existence of electrical and transportation usage rule and waste reduction practices. The company also made sure to use more eco-friendly product materials to make sure their products meet the safety requirements.

Encourage Stewardship: aims to make sure that the company produces sustainable and innovative products for their consumers through the creation of improved marketing and financing processes, creating more sustainable technology, etc. and provide higher quality of life for their employees (Pal et al., 2017). In Daliatex Company, the application of this strategy is supported by the creation of several efforts in increasing the quality of life of their employees, like providing a healthy and safe environment, health and sports facilities, and balance work hours for their employees. In relation with their consumers, the company also communicates the value and quality of their products to their consumers by promote a campaign called "buy less for more" which means that with the money of their consumers' spent for their products, there are many benefits that they will get, like sustainable, high quality, eco-friendly products, etc.

\subsubsection{Organizational / Economical Innovation}

Re-purpose the business for society/environment: related to the application of social entrepreneurship in managing the company's business. The company's trying to give more benefit to the society around their factory to enhance their economic condition. This concept relates to the application of waste reduction programs to reduce the number of waste and increase the quality of their waste so that the waste is not harmful for the environment, even if the company can reuse the waste for other beneficial purposes rather than throw it away since it can pollute the environment.

Develop Scale-Up Solution: related to how companies create collaboration with other parties to scale-up their business through the implementation of open innovation and co-creation. Then, to reduce their cost, the company is trying to optimize the digitization era through online marketing and reducing the use of steel, aluminum, and plastic in their production activity.

\section{Conclusions}

This study has examined the implementation of sustainable manufacturing (SM) practices in the Indonesian leading textile manufacturer. In general, empirical evidence from this research showed that the evaluation result for the practice of sustainable manufacturing in the company studied is quite good. The company has applied three pillars of sustainability in their company, which are economic, social, and environmental dimensions. The results reveal that they have adopted an integrated and collaborative approach to reach sustainability in their company, from medium to high implementation. Considering their objective is to produce a high quality knit products and to make sure that the products are marketable and producible, the implementation of SM concept in their company give high impact to the improvement of sustainability of the company, in terms of economic, social, and environment context, so that currently, they can be one of the leading textile in Indonesia.

By providing information about the implementation of SM practice in the textile sector in Indonesia, this study can be a reference for stakeholders involved, not only in the textile sector, but manufacturing sector as well. Through the implementation of SM, companies can improve their production processes to attain a better performance in the economic, social, and environmental aspects. This study also is expected to give more insight for the government and other stakeholders in making better decisions to enhance the performance of the manufacturing industry in Indonesia. 
Then, for scholars, this research can be a literature in conducting research related to the SM implementation so it can bring new discoveries in the future. Since this study is only limited to one object, it is suggested that in the future, scholars can add more objects to get rich insight and comparison regarding the best SM model to be implemented, with more varied sectors.

\section{References}

Amaranti, R., Irianto, D., \& Govindaraju, R. (2017). Green Manufacturing: Kajian Literatur. Seminar dan Konferensi Nasional IDEC, 8, 2579-6429.

Ariyanti, F. D. (2018). Green supply chain practices in Indonesia's industries. IOP Conference Series: Earth and Environmental Science, 195(1). https://doi.org/10.1088/17551315/195/1/012028

Bhanot, N., Rao, P. V., \& Deshmukh, S. G. (2015). Sustainable Manufacturing: An Interaction Analysis for Machining Parameters using Graph Theory. Procedia - Social and Behavioral Sciences, 189, 57-63. https://doi.org/10.1016/j. sbspro.2015.03.192

Bocken, N. M. P., Short, S. W., Rana, P., \& Evans, S. (2014). A literature and practice review to develop sustainable business model archetypes. Journal of Cleaner Production, 65(September), 42-56. https://doi.org/10.1016/j.jclepro.2013. 11.039

Choi C., Kim, C., \& Kim, C. (2019). Towards Sustainable Environmental Policy and Management in the Fourth Industrial Revolution: Evidence from Big Data Analytics. Journal of Asian Finance, Economics and Business, 6(3), 185-192. https:// doi.org/10.13106/jafeb.2019.vol6.no3.185

Djunaidi, M., Sholeh, M. A. A., \& Mufiid, N. M. (2018). Analysis of green supply chain management application in Indonesian wood furniture industry. AIP Conference Proceedings, 1977(June). https://doi.org/10.1063/1.5042906

EPA. (2010). U.S. Environmental Protection Agency: 2015 Strategic Sustainability Performance Plan. EPA Website. Retrieved June 10, 2020 (actual access date), from https:// www.epa.gov/sites/production/files/2015-11/documents/epa_ strategic_sustainability_performance_plan_2015.pdf

Fatimah, Y. A., Biswas, W., Mazhar, I., \& Islam, M. N. (2013). Sustainable manufacturing for Indonesian small- and mediumsized enterprises (SMEs): The case of remanufactured alternators. Journal of Remanufacturing, 3(1). https://doi. org/10.1186/2210-4690-3-6

Gam, H.J., Cao, H., Farr, C., \& Heine, L. (2009). C2CAD: A sustainable apparel design and production model. International Journal of Clothing Science and Technology, 21(4), 166-179. https://doi.org/10.1108/09556220910959954
Hami, N., Muhamad, M. R., \& Ebrahim, Z. (2015). The impact of sustainable manufacturing practices and innovation performance on economic sustainability. Procedia CIRP, 26(June), 190-195. https://doi.org/10.1016/j.procir.2014.07.167

Hanafi, J. (2016). Menuju manufaktur berkelanjutan di Indonesia: Tantangan dan Kesempatan. Jurnal Teknik Industri, 17(2). https://doi.org/10.9744/jti.17.2.123-132

Jones, P., Hillier, D., \& Comfort, D. (2016). The Sustainable Development Goals and the Financial Services Industry. Athens Journal of Business \& Economics, 3(1), 37-50. https://doi. org/10.30958/ajbe.3.1.3

Khan, U., Haque, M. I., \& Khan, A. M. (2020). Environmental Sustainability Awareness in the Kingdom of Saudi Arabia. Journal of Asian Finance, Economics and Business, 7(9), 687-695. https://doi.org/:10.13106/jafeb.2020.vol7.no9.687

Moldavska, A., \& Welo, T. (2017). The concept of sustainable manufacturing and its definitions: A content-analysis based literature review. Journal of Cleaner Production, 166, 744-755. https://doi.org/10.1016/j.jclepro.2017.08.006

Nguyen, A. H., \& Nguyen, L. H. (2020). Determinants of Sustainability Disclosure: Empirical Evidence from Vietnam. Journal of Asian Finance, Economics and Business, 7(6), 73-84. https://dpoi.or/10.13106/jafeb.2020.vol7.no6.073

Nurlanova, N. K., Omarov, A. K., \& Satpayeva, Z. T. (2020). Methodological Approaches to Estimation of Economic Growth and Sustainable Development: Kazakhstan's Experience. Journal of Asian Finance, Economics and Business, 7(4), 317-324. https://doi.org/10.13106/jafeb.2020.vol7.no4.317

Pal, R. (2017). Sustainable Design and Business Models in Textile and Fashion Industry. October, 109-138. https://doi. org/10.1007/978-981-10-2639-3_6

Roespinoedji, R., Mulyawan, F., Prawira, A., Abidin, I. S. Z., \& Chankoson, T. (2019). The effect of green supply chain practices on Indonesian Manufacturing Small and Medium Enterprises (SMEs). International Journal of Supply Chain Management, 8(2), 189-197.

Sangwan, K. S. (2011). Development of a multi criteria decision model for justification of green manufacturing systems. International Journal of Green Economics, 5(3), 285-305. https://doi.org/10.1504/IJGE.2011.044239

Sangwan, K. S., \& Mittal, V. K. (2015). Management of Environmental Quality: An International Journal A bibliometric analysis of green manufacturing and similar frameworks. An International Journal Measuring Business Excellence Industrial Management, 26(5), 566-587. https://doi.org/10.1108/MEQ02-2014-0020

Thaib, D. (2020). Drivers of the green supply chain initiatives: Evidence from indonesian automotive industry. Uncertain Supply Chain Management, 8(1), 105-116. https://doi. org/10.5267/j.uscm.2019.8.002 